\title{
A STUDY OF THE RESIDUAL EFFECTS OF PHOSGENE POISONING IN HUMAN SUBJECTS. II. AFTER CHRONIC EXPOSURE
}

\author{
By MORTON GALDSTON,1 JOHN A. LUETSCHER, JR., WARFIELD T. LONGCOPE, \\ AND NICHOLAS L. BALLICH WITH THE ASSISTANCE OF VIRGINIA L. \\ KREMER, GILES L. FILLEY, AND JOHN L. HOPSON \\ (From the Clinical Research Section, Medical Division, Chemical Warfare Service, Edgewood \\ Arsenal, Maryland, and the Department of Medicine, Johns Hopkins \\ Hospital, Baltimore, Maryland ${ }^{2}$ )
}

(Received for publication March 4, 1946)

\section{INTRODUCTION}

In contrast to the serious consequences of a single, heavy exposure to phosgene, distressing symptoms and disability are uncommon among workers repeatedly exposed to small amounts of phosgene over a period of years. Physical and roentgenographic examinations of such workers have revealed a relatively low incidence of disease of the lungs (1). There are no reports, as far as we are aware, of detailed studies of the function of the lungs in such individuals.

\section{EXPERIMENTAL}

Five workers, who had repeated exposures to small amounts of phosgene during the course of $11 / 2$ to $31 / 2$ years, were studied with particular emphasis on pulmonary function and cardiovascular and psychiatric status. The methods employed have been previously described (2).

\section{RESULTS}

Clinical summaries and data on pulmonary and cardiovascular function studies are presented in detail in the Appendix and summarized in Table I.

\section{DISCUSSION}

Most of the patients had experienced on several occasions transitory symptoms from inhalation of phosgene. Over a period of several months, all of these patients developed cough, shortness of breath on exertion, and pain or tightness of the chest, in varying degrees of severity. Sputum was scanty and mucoid. Symptoms improved on removal of the worker from exposure for several weeks.

1 Captain, MC, A.U.S.

2 Study carried out at the Johns Hopkins Hospital, Baltimore, Maryland, under a contract with the OEMcmr and a Medical Division, OC, CWS, Work Project Specification.
Two of the patients (cases 2 and 3 ) exhibited well-marked physical and roentgenographic evidence of emphysema of the lungs, which was confirmed by an increased proportion of residual air, a definite impairment of intrapulmonary mixing of gases, prolonged pulmonary emptying of nitrogen, a limited voluntary breathing capacity, and a discrepancy between the tension of oxygen in alveolar air and arterial blood.

Anoxemia was not observed in these patients despite the well-marked ventilatory abnormalities.

One of these patients (case 3 ) had a history of attacks suggestive of bronchial asthma, and it is impossible to evaluate the effect of the repeated exposures to phosgene.

Two other patients (cases 1 and 4), who presented no clinical evidence of disease of the lungs, showed abnormalities of lung volume and intrapulmonary mixing of gases. Case 4 also had an arterial blood oxygen tension considerably below the alveolar air oxygen tension during exercise. These patients' objective abnormalities are equally as severe as those found in the presence of clinical signs of emphysema (cases 2 and 3 ).

One patient (case 5), whose chief complaint was shortness of breath on exertion, showed a reduction in voluntary breathing capacity without any clinical or other functional evidence of pulmonary disease.

The pattern of breathing in three patients (cases $2,3,4)$ was similar to that observed after acute exposure to phosgene (2). The rapid, shallow breathing was present at rest and after exercise and was associated with a subnormal extraction of oxygen per volume of air breathed.

The patients were generally seen by the psychiatrist on only one or two occasions. They appeared to be stable and not unduly disturbed about their symptoms. One patient (case 4) was under 
stress from a difficult situation at home, but this did not reflect itself in a tendency to exaggerate his symptoms.

Psychological factors appear to be of little consequence in their symptoms. This is in contrast to the patients studied following acute exposure to phosgene (2). This difference between the acutely and chronically exposed patients may be related to the stability of these latter patients, the lack of an isolated severe traumatic episode, or the less disturbing character of their symptoms. The previous personality structure and sources of emotional support in the form of wholesome personal contacts and secure environments seem to be significant factors.

\section{CONCLUSIONS}

1. Emphysema of the lungs may develop after chronic exposure to phosgene.

2. The measurable disturbances of the lungs are more striking after chronic exposure to phosgene than after recovery from a serious acute exposure.

TABLE I

Summary of clinical observations and data on studies performed

\begin{tabular}{|c|c|c|c|c|c|}
\hline Case Number*. & 1 & 2 & 3 & 4 & 5 \\
\hline $\begin{array}{l}\text { Patient's initials } \\
\text { Age } \\
\text { Months worked with phosgene } \\
\text { Chronic symptoms } \\
\text { Physical signs: Acute } \\
\text { Chronic } \\
\text { Roentgenogram of chest } \\
\text { Volume: vital capacity } \\
\frac{\text { Per cent residual air }}{\text { Total capacity }} \\
\text { Intrapulmonary mixing of gases } \\
\text { Pulmonary emptying } \\
\text { Resting } \\
\text { pattern of }\left\{\begin{array}{l}\text { High rate } \\
\text { breathing tidal air } \\
\text { High min. volume } \\
\text { Low O2 extraction }\end{array}\right. \\
\text { Exercise } \\
\text { pattern of }\left\{\begin{array}{l}\text { High rate } \\
\text { Low tidal air } \\
\text { bow O2 extraction }\end{array}\right. \\
\text { Arterial blood** }\left\{\begin{array}{l}\text { Rest } \\
\text { Exercise } \\
\text { Oxygen }\end{array}\right. \\
\text { Breath-holding } \\
\text { Voluntary breathing capacity } \\
\text { Postural tests } \\
\text { Cardiac output }\end{array}$ & $\begin{array}{l}\mathbf{W . L} \\
\mathbf{3 2} \\
\mathbf{4 2} \\
\mathbf{A} \\
\mathbf{N} \\
\mathbf{N} \\
\mathbf{N} \\
\mathbf{A} \\
\mathbf{A} \\
\mathbf{A} \\
\mathbf{N} \\
\mathbf{N} \\
\mathbf{N} \\
\mathbf{N} \\
\mathbf{N} \\
\mathbf{N} \\
\mathbf{N} \\
\mathbf{N} \\
\mathbf{N} \\
\mathbf{N} \\
\mathbf{N} \\
\mathbf{N} \\
\mathbf{N} \\
\mathbf{N} \\
\mathbf{N}\end{array}$ & $\begin{array}{l}\text { C.E. } \\
\mathbf{5 0} \\
\mathbf{3 6} \\
\mathbf{A} \\
\mathbf{N} \\
\mathbf{B} \\
\mathbf{A} \\
\mathbf{N} \\
\mathbf{B} \\
\mathbf{A} \\
\mathbf{B} \\
\mathbf{A} \\
\mathbf{A} \\
\mathbf{A} \\
\mathbf{N} \\
\mathbf{B} \\
\mathbf{B} \\
\mathbf{N} \\
\mathbf{A} \\
\mathbf{N} \\
\mathbf{A} \\
\mathbf{A} \\
\mathbf{A}\end{array}$ & $\begin{array}{c}\text { T.C. } \\
\mathbf{2 4} \\
\mathbf{3 0} \\
\mathbf{A} \\
\mathbf{N} \\
\mathbf{A} \\
\mathbf{A} \\
\mathbf{B} \\
\mathbf{A} \\
\mathbf{A} \\
\mathbf{A} \\
\mathbf{A} \\
\mathbf{A} \\
\mathbf{A} \\
\mathbf{B} \\
\mathbf{B} \\
\mathbf{B} \\
\mathbf{A} \\
\mathbf{N} \\
\mathbf{A} \\
\mathbf{-} \\
\mathbf{A} \\
\mathbf{N}\end{array}$ & $\begin{array}{c}\mathbf{A . L} . \mathbf{3} \\
\mathbf{3 1} \\
\mathbf{1 6} \\
\mathbf{A} \\
\mathbf{N} \\
\mathbf{N} \\
\mathbf{N} \\
\mathbf{N} \\
\mathbf{B} \\
\mathbf{A} \\
\mathbf{A} \\
\mathbf{A} \\
\mathbf{B} \\
\mathbf{A} \\
\mathbf{A} \\
\mathbf{B} \\
\mathbf{B} \\
\mathbf{A} \\
\mathbf{N} \\
\mathbf{A} \\
\mathbf{N} \\
\mathbf{N} \\
\mathbf{N} \\
\mathbf{N}\end{array}$ & $\begin{array}{c}\mathbf{I} \mathbf{H} \\
\mathbf{2 6} \\
\mathbf{3 0} \\
\mathbf{A} \\
\mathbf{N} \\
\mathbf{N} \\
\mathbf{N} \\
\mathbf{N} \\
\mathbf{N} \\
\mathbf{N} \\
\mathbf{N} \\
\mathbf{N} \\
\mathbf{N} \\
\mathbf{N} \\
\mathbf{N} \\
\mathbf{N} \\
\mathbf{N} \\
\mathbf{N} \\
\mathbf{-} \\
\mathbf{Z} \\
\mathbf{N} \\
\mathbf{A} \\
\mathbf{Z}\end{array}$ \\
\hline
\end{tabular}

$\mathrm{A}=$ Definitely abnormal. $\mathrm{B}=$ Borderline abnormal. $\mathrm{N}=$ Normal. $\underline{B}=$ Not done.

${ }^{*}$ Listed in order studied.

** Arterial blood oxygen and alveolar air oxygen and carbon dioxide tension studies at rest and after exercise were performed 4 to 8 months after all other studies were completed. Symptoms, physical and roentgenographic findings were unchanged on re-examination of all available patients (all except 5 ) at that time.
3. The symptoms of chronic exposure to phosgene have not been disabling, in contrast to the frequent prolonged disability seen after acute exposure.

\section{APPENDIX}

Clinical summaries and data on pulmonary and circulatory function studies. Case histories of patients 1 through 5 are given below. The results of the pulmonary function studies are presented in Figures $1 \mathrm{~A}, 1 \mathrm{~B}, 1 \mathrm{C}$ through $5 \mathrm{C}$ and in Tables IA, IB through IVB and Table VA. The number of each figure and table corresponds to the case number listed in Table I.

Legend for figures on intrapulmonary mixing of gases. The data are presented in Figures 1B through $5 \mathrm{~B}$ and $1 \mathrm{C}$ through $5 \mathrm{C}$. The method of presentation is the same as previously described (2).

Legend for figures on subdivisions of lung volume (Figures $1 A$ through 5A). Standards for comparison and manner of presentation are the same as described under methods (2).

Legend for Tables IA through $V A, V B, V C$, are the same as for Tables IA through VIC of Appendix in previous report (2).

Case 1 (W. L., Male, Age 32, Record No. 325055).

Height $164 \mathrm{~cm}$., Weight $80.7 \mathrm{kgm}$., Surface Area $1.78 \mathrm{M}^{2}$.

The patient voluntarily entered the Johns Hopkins Hospital on June 26, 1944, for study of his pulmonary function.

His past history is non-contributory.

Since January 2,1944, he has been working as a supervisor in gas warfare agent production plants of Edgewood Arsenal. He has been supervising phosgene production most of the time.

$\mathrm{He}$ experienced moderate conjunctivitis during the early part of 1941 and conjunctivitis and laryngitis in the fall of 1943 when he worked with mustard.

From March 6 through March 9, 1941, he accidentally inhaled small amounts of phosgene on several different occasions. This caused a sense of constriction in the chest, dizziness, mental confusion, blurred vision, and severe headaches.

On July 15, 1941, he experienced severe irritation of the throat from inhaling chlorine.

He worked steadily in the phosgene plant from October, 1943, until he entered the hospital on January 26, 1944. During the 10 days prior to entering the hospital he experienced a sensation of tightness in the chest, slight shortness of breath on exertion, and nervous twitchings in different muscles which he ascribed to recent minor exposures to phosgene. 


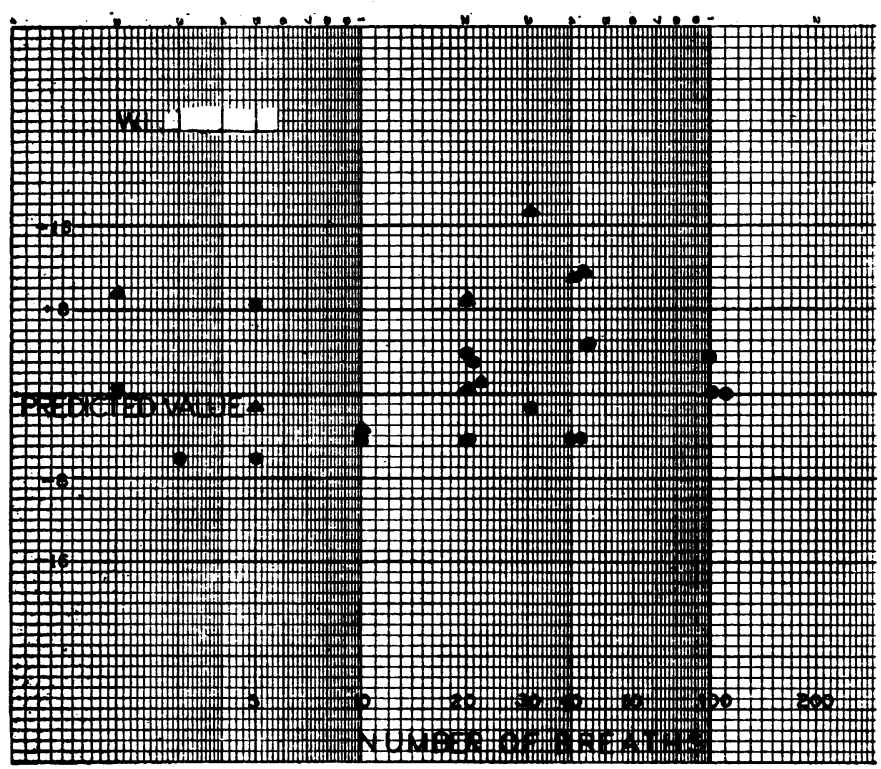

$1 B$

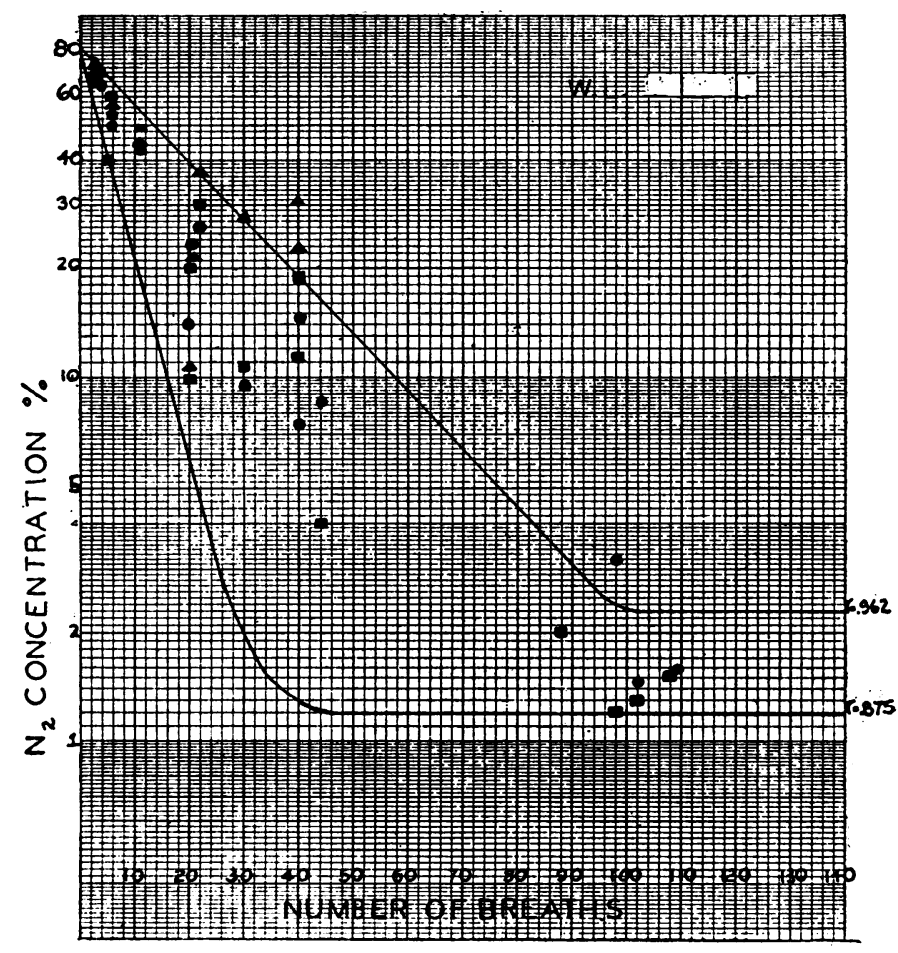

$1 \mathrm{C}$

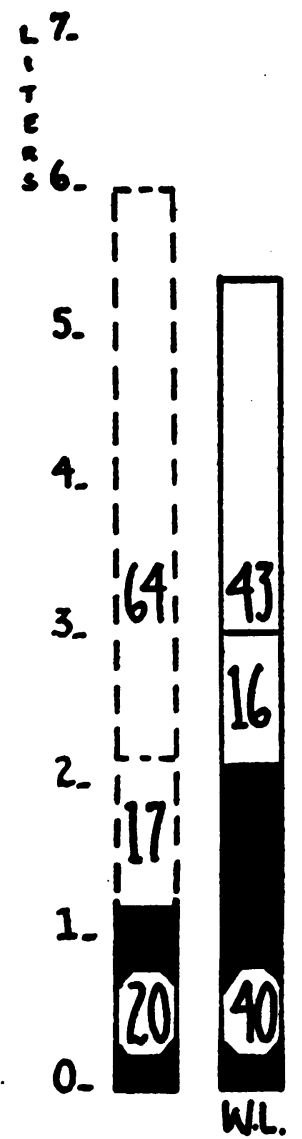

$1 \mathrm{~A}$

Fig. 1A. Subdivisions of Lung Volume. 1B and 1C. Intrapulmonary Mixing of Gases-Tidal Air: 348$700 \mathrm{ml}$. (generally $500 \mathrm{ml}$.). Dead Space: $265 \mathrm{ml}$. 
At the time of his admission to the hospital, no abnormal findings were noted on physical examination.

A roentgenogram of the heart and lungs and an electrocardiogram were normal. The red blood count, level of hemoglobin, total and differential white blood counts, and urine were normal.

When seen again in January, 1945, approximately 6 months after the initial observation, the patient was still working in the phosgene plant. There had been no progression of symptoms. There were no new complaints or physical findings.

PULMONARY FUNCTION STUDIES: The vital capacity is reduced below the lower limit of normal variation due primarily to a low complementary air. The residual air and the mid-capacity are large and comprise abnormally high portions of the total lung volume. The ratio of complementary air to total capacity is far below the limit of normal variation (Figure 1A).

The resting respiratory rate, tidal air, and minute volume are normal. On exercise there is a marked increase in tidal air; respiratory rate does not change and the minute volume remains within the normal range. The oxygen extraction and carbon dioxide output per volume of air breathed at rest is normal, rises close to the upper limit of normal variation during exercise, and remains there during the 2 minutes immediately following exercise (Table IA).

The lung nitrogen dilution rate is slow primarily because of a large mid-capacity. Intrapulmonary mixing of gases is abnormal. Pulmonary emptying rate is normal (Figures 1B, 1C).

The arterial blood and alveolar air oxygen tension studies indicate that there is no disturbance in gaseous exchange in the lungs at rest and during exercise. There is no anoxemia (Table IB).

TABLE IA

Respiratory pattern resting

\begin{tabular}{|c|c|c|c|c|c|c|c|c|}
\hline \multirow{2}{*}{$\begin{array}{l}\text { Date } \\
1944\end{array}$} & \multirow{2}{*}{$\begin{array}{c}\text { Experi- } \\
\text { ment }\end{array}$} & \multirow{2}{*}{$\begin{array}{l}\text { Resp. } \\
\text { rate }\end{array}$} & \multirow{2}{*}{$\begin{array}{c}\text { Tidal } \\
\text { air }\end{array}$} & \multirow{2}{*}{$\begin{array}{l}\text { Min: } \\
\text { vol. }\end{array}$} & \multicolumn{2}{|c|}{ Alveolar air } & \multicolumn{2}{|c|}{ Expired air } \\
\hline & & & & & $\mathrm{pO}_{2}$ & $\mathrm{pCO}_{2}$ & $\mathrm{O}_{2}$ & $\mathrm{CO}_{2}$ \\
\hline $\begin{array}{l}6 / 27 \\
6 / 29 \\
6 / 30\end{array}$ & $\begin{array}{l}\mathrm{Air} \\
\mathrm{O}_{2} \\
\mathrm{Air} \\
\mathrm{O}_{2} \\
\mathrm{O}_{2} \\
\mathrm{O}_{2}\end{array}$ & $\begin{array}{l}16.5 \\
14.0 \\
13.0 \\
14.5 \\
12.5 \\
13.5\end{array}$ & $\begin{array}{l}m l . \\
488 \\
497 \\
535 \\
544 \\
439 \\
647\end{array}$ & $\begin{array}{c}l . \\
\mathbf{8 . 0 7} \\
7.67 \\
7.03 \\
\mathbf{7 . 8 9} \\
\mathbf{5 . 4 5} \\
\mathbf{8 . 7 4}\end{array}$ & $\begin{array}{r}94.2 \\
660.0 \\
99.1 \\
658.0 \\
485.0 \\
510.0\end{array}$ & $\begin{array}{l}43.1 \\
42.0 \\
41.4 \\
45.3 \\
45.3 \\
36.7\end{array}$ & $\begin{array}{c}\text { per } \\
\text { cent } \\
17.5 \\
\overline{17.3} \\
= \\
-\end{array}$ & $\begin{array}{l}\text { per } \\
\text { cent } \\
2.80 \\
2.70 \\
3.30 \\
2.70 \\
\overline{3.05}\end{array}$ \\
\hline
\end{tabular}

Exercise *

\begin{tabular}{|c|c|c|c|c|c|c|c|c|}
\hline $\begin{array}{l}\text { Date } \\
1944\end{array}$ & State & W & & $\begin{array}{c}\text { Resp. } \\
\text { rate }\end{array}$ & $\begin{array}{c}\text { Tidal } \\
\text { air }\end{array}$ & $\begin{array}{l}\text { Min. } \\
\text { vol. }\end{array}$ & $\begin{array}{l}\mathrm{O}_{2} \text { ex- } \\
\text { trac- } \\
\text { tion }\end{array}$ & $\begin{array}{l}\mathrm{CO}_{2} \\
\text { out- } \\
\text { put }\end{array}$ \\
\hline $6 / 29$ & $\begin{array}{l}\text { Resting } \\
\text { Exercise } 0^{\prime}-1^{\prime} \\
\text { Recovery } 1^{\prime}-2^{\prime} \\
\text { Recovery } 2^{\prime}-3^{\prime}\end{array}$ & $\begin{array}{c}f t .-l b . \\
= \\
=\end{array}$ & $\begin{array}{c}\text { kgm.- } \\
m . \\
= \\
= \\
-\end{array}$ & $\begin{array}{l}13 \\
12 \\
13 \\
13\end{array}$ & $\begin{array}{c}m l . \\
535 \\
1,235 \\
1,355 \\
1,254\end{array}$ & $\begin{array}{r}l . \\
7.0 \\
14.8 \\
17.6 \\
16.3\end{array}$ & $\begin{array}{l}\text { vol. } \\
\text { per } \\
\text { cent } \\
3.63 \\
\overline{7.63} \\
6.03\end{array}$ & $\begin{array}{c}\text { vol. } \\
\text { per } \\
\text { cent } \\
3.27 \\
\overline{5.77} \\
5.47\end{array}$ \\
\hline
\end{tabular}

* Bicycle ergometer.
TABLE IB

Arterial blood studies

\begin{tabular}{|c|c|c|c|c|c|c|c|}
\hline $\begin{array}{l}\text { Date } \\
1944\end{array}$ & State & $\begin{array}{l}\mathrm{CO}_{2} \\
\text { con- } \\
\text { tent }\end{array}$ & $\mathrm{pH}$ & $\mathrm{pCO}_{2}$ & $\begin{array}{c}\mathrm{O}_{2} \\
\text { con- } \\
\text { tent }\end{array}$ & $\begin{array}{c}\mathrm{O}_{2} \\
\text { capa- } \\
\text { city }\end{array}$ & $\begin{array}{l}\text { Satu- } \\
\text { ration }\end{array}$ \\
\hline & & $\begin{array}{c}\text { ool. } \\
\text { per cent }\end{array}$ & & & $\begin{array}{c}\text { ool. } \\
\text { per cent }\end{array}$ & $\begin{array}{c}\text { ool. } \\
\text { per cent }\end{array}$ & $\begin{array}{l}\text { per } \\
\text { cent }\end{array}$ \\
\hline $6 / 30$ & $\begin{array}{l}\text { Room air } \\
\text { Oxygen }\end{array}$ & $\begin{array}{l}55.7 \\
55.1\end{array}$ & $\begin{array}{l}7.30 \\
7.35\end{array}$ & $\begin{array}{l}49 \\
53\end{array}$ & $\begin{array}{l}19.8 \\
20.9\end{array}$ & $\begin{array}{l}20.5 \\
20.5\end{array}$ & $\begin{array}{r}96.6 \\
102.0\end{array}$ \\
\hline
\end{tabular}

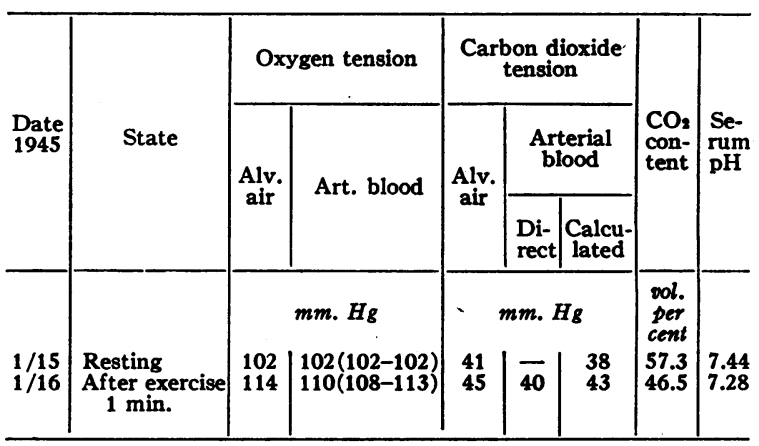

The voluntary breathing capacity in the erect posture is 127.6 liters. This is 102.6 per cent of the predicted value. The duration of breath-holding is normal.

The results of the tilt table studies are normal, except for a sustained tachycardia (100) in the erect posture. In the supine posture the pulse rate is 64 per minute. The cardiac output is 1.73 liters per minute per square meter body surface area. This is a normal value.

SUMMARY: There is impaired ventilatory function of the lungs as indicated by an absolute decrease in vital capacity, abnormally high relative volumes of mid-capacity and residual air, slow dilution rate, and impaired intrapulmonary mixing of gases. The respiratory function of the lungs is not impaired.

These findings are consistent with pulmonary emphysema.

Case 2 (C. E., Male, Age 50, Record No. 326252). Height $165 \mathrm{~cm}$., Weight $77 \mathrm{kgm}$., Surface Area $1.83 \mathrm{M}^{2}$.

The patient voluntarily entered the Johns Hopkins Hospital on July 9, 1944, for pulmonary function studies.

His past history is non-contributory.

The patient has worked as a machinist in the phosgene plant, Edgewood Arsenal, since May, 1941. He has had numerous minor exposures to phosgene. These are generally followed by a sense of contriction in the throat, breathlessness, cough, nausea and vomiting of several minutes to hours duration.

He has experienced increasing shortness of breath on moderate exertion for about $3 \frac{1}{2}$ years, since the middle of 1941. For about one year there has been frequent cough productive of yellowish, thick sputum, which occasionally tastes of phosgene and has an offensive odor.

At the time of his admission to the hospital, no abnormalities were noted on physical examination. 


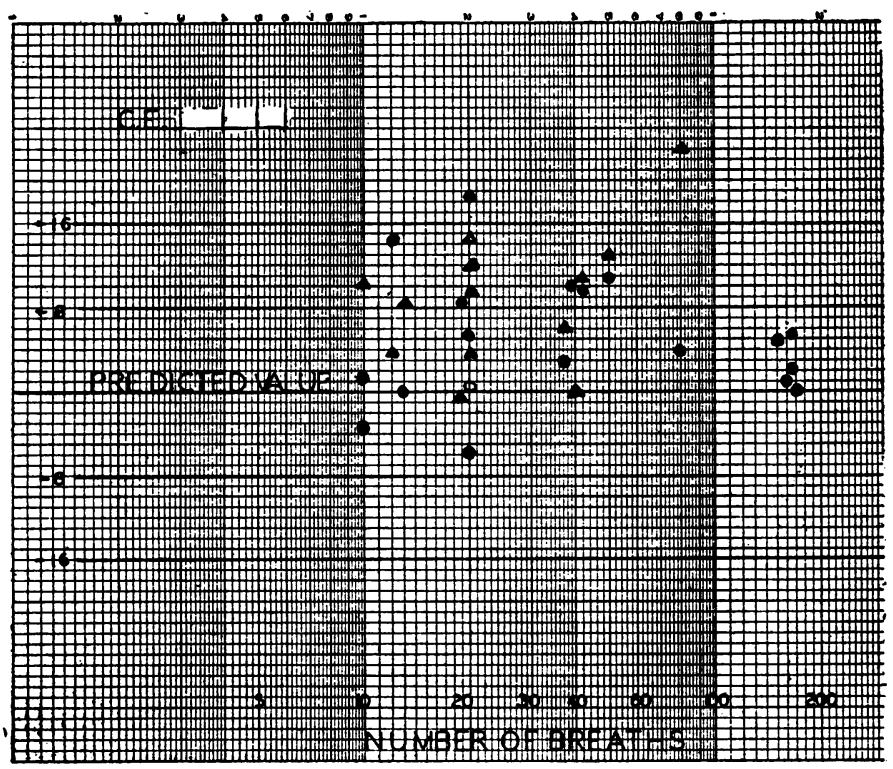

$2 B$

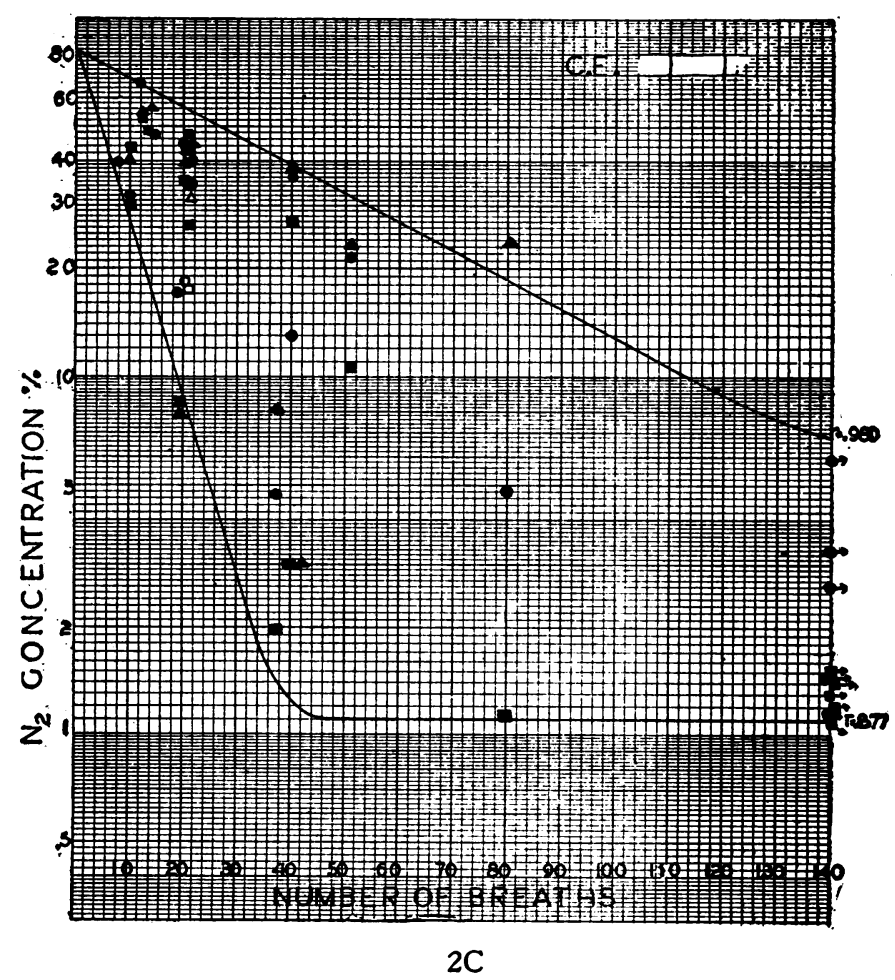

$i^{2}$
6
6

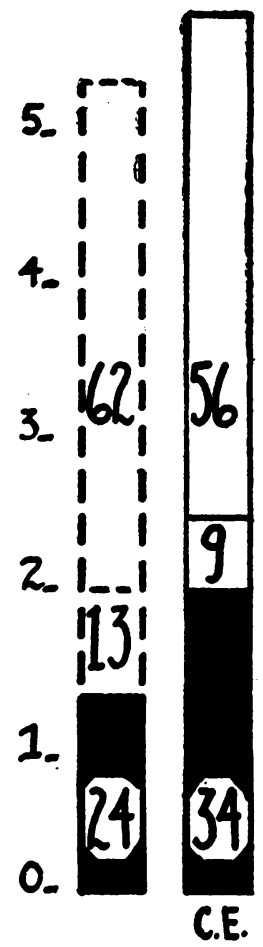

$2 \mathrm{~A}$

Fig. 2A. Subdivisions of Lung Volume. 2B and 2C. Intrapulmonary Mixing of Gases-Tidal Air: 213-537 ml. (generally $350 \mathrm{ml}$.), voluntarily deepened $410 \mathrm{ml}$. DeAd Space: $153 \mathrm{ml}$. (Tidal Air below $350 \mathrm{ml}$.), $205 \mathrm{ml}$. (Tidal Air above $350 \mathrm{ml}$.). 
The patient was without complaint except for an occasional cough and expectoration of small amounts of tenacious, yellow, non-foul sputum.

Pulmonary emphysema was suggested by the appearance of roentgenograms. The blood counts, urine, chemical studies, and level of venous pressure were normal.

When last seen in January, 1945, approximately 6 months after the initial examination, there were no new complaints or progression of the symptoms previously noted; physical and laboratory findings were unchanged.

PSYCHIATRIC SUMMARY: C. E. seems to be a fairly sensible, stable fellow, who returns to the hospital at this time (January 16, 1945) for follow-up study. He has no particular complaint. From the psychiatric standpoint he presents no remarkable findings. His exposures, while repeated, seem to have not been very disabling from the physical or emotional standpoint. His attitude toward these experiments is quite reasonable, he seems to have been not unduly distressed by the incidents, his emotional reaction is quite appropriate, and his personal adjustment to these events, in general, is quite good. He has been able to work regularly, has been able to adjust his life very well, and he seems happy. There seems to have been no serious personality deviation.

TABLE IIA

Respiratory pattern resting

\begin{tabular}{|c|c|c|c|c|c|c|c|c|}
\hline \multirow{2}{*}{$\begin{array}{l}\text { Date } \\
1944\end{array}$} & \multirow{2}{*}{$\begin{array}{c}\text { Experi- } \\
\text { ment }\end{array}$} & \multirow{2}{*}{$\begin{array}{c}\text { Resp. } \\
\text { rate }\end{array}$} & \multirow{2}{*}{$\begin{array}{l}\text { Tidal } \\
\text { air }\end{array}$} & \multirow{2}{*}{$\begin{array}{c}\text { Min. } \\
\text { vol. }\end{array}$} & \multicolumn{2}{|c|}{ Alveolar air } & \multicolumn{2}{|c|}{ Expired air } \\
\hline & & & & & $\mathrm{pO}_{2}$ & $\mathrm{pCO}_{2}$ & $\mathrm{O}_{2}$ & $\mathrm{CO}_{2}$ \\
\hline $\begin{array}{c}7 / 10 \\
7 / 11 \\
7 / 12\end{array}$ & $\begin{array}{c}\text { Air } \\
\mathrm{O}_{2} \\
\mathrm{O}_{2} \\
\mathrm{Air} \\
\mathrm{O}_{2} \\
\mathrm{O}_{2} \\
\mathrm{Air} \\
\mathrm{O}_{2} \\
\mathrm{O}_{2} \\
\mathrm{Air} \\
\mathrm{O}_{2} \\
\mathrm{O}_{2} \\
\mathrm{O}_{2} \\
\mathrm{Air}_{1} \\
\mathrm{O}_{2} \\
\mathrm{O}_{2} \\
\mathrm{O}_{2}\end{array}$ & $\begin{array}{l}\overline{25.0} \\
26.0 \\
38.5 \\
23.0 \\
27.0 \\
22.5 \\
27.5 \\
27.0 \\
24.5 \\
24.0 \\
22.0 \\
22.0 \\
20.5 \\
23.5 \\
21.5 \\
25.0\end{array}$ & $\begin{array}{l}m l . \\
358 \\
349 \\
448 \\
508 \\
400 \\
356 \\
379 \\
330 \\
342 \\
344 \\
367 \\
269 \\
361 \\
393 \\
353 \\
381 \\
361\end{array}$ & \begin{tabular}{r|}
\multicolumn{1}{c}{$l}$. \\
8.78 \\
11.65 \\
19.63 \\
9.43 \\
9.66 \\
8.49 \\
9.08 \\
9.26 \\
8.34 \\
8.77 \\
5.88 \\
7.94 \\
8.09 \\
8.32 \\
8.23 \\
9.07
\end{tabular} & $\begin{array}{c}\overline{-} \\
621.0 \\
\bar{z} \\
\overline{109.2} \\
\bar{z} \\
77.4 \\
644.0 \\
493.0 \\
649.0 \\
91.2 \\
620.0 \\
-\end{array}$ & $\begin{array}{l}\bar{Z} \\
42.1 \\
\overline{-} \\
\bar{Z} \\
45.1 \\
\overline{-} \\
60.8 \\
42.4 \\
45.1 \\
42.0 \\
43.5 \\
39.9 \\
-\end{array}$ & $\begin{array}{c}\text { per } \\
\text { cent } \\
17.47 \\
= \\
= \\
\bar{Z} \\
17.66 \\
\overline{-} \\
= \\
\bar{Z} \\
\overline{17.60} \\
\overline{-}\end{array}$ & $\begin{array}{c}\text { per } \\
\text { cent } \\
2.83 \\
= \\
\overline{-} \\
\overline{\bar{一}} \\
2.70 \\
2.70 \\
\overline{-} \\
\overline{-} \\
2.07 \\
2.30 \\
2.97 \\
2.88 \\
= \\
\overline{-}\end{array}$ \\
\hline
\end{tabular}

Exercise*

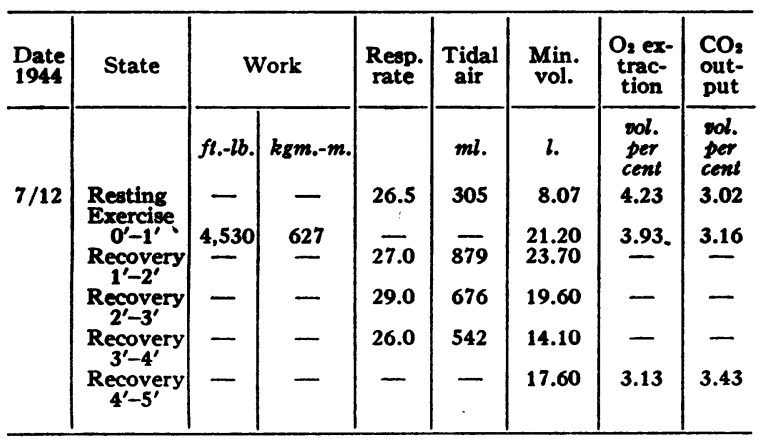

* Step test.
TABLE IIB

Arterial blood studies

\begin{tabular}{|c|c|c|c|c|}
\hline Date 1944 & State & $\mathrm{O}_{2}$ content & $\mathrm{O}_{2}$ capacity & Saturation \\
\hline $7 / 12$ & Resting & $\begin{array}{c}\text { vol. per cent } \\
17.4\end{array}$ & $\begin{array}{c}\text { vol. per cent } \\
17.2\end{array}$ & $\begin{array}{c}\text { per cent } \\
101.0\end{array}$ \\
\hline
\end{tabular}

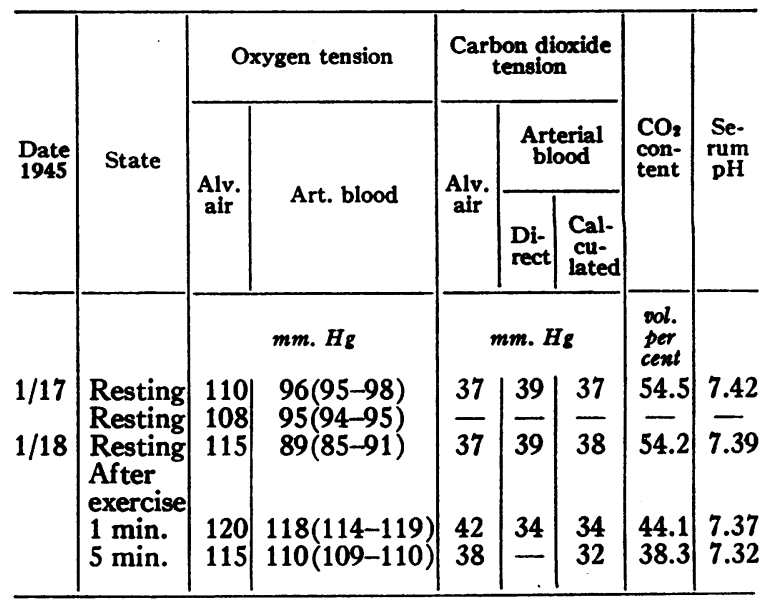

PULMONARY FUNCTION STUdIES: The vital capacity is normal. The volume of residual air comprises a relatively high per cent of the total lung volume (Figure 2A).

The respiratory rate during rest is rapid, tidal air is usually lower than normal, and minute volume is high. Breathing oxygen does not alter the pattern of respiration. During exercise the minute volume increases within the normal range primarily by a rise in tidal air.

The carbon dioxide tension of alveolar air exceeds by far the normal range of variation and cannot be accounted for by breath-holding prior to collection of the alveolar sample. It would appear to be a reflection of impaired intrapulmonary mixing.

The oxygen extraction and carbon dioxide output are normal at rest, during exercise, and during recovery from exercise (Table IIA). The oxygen tension of arterial blood is significantly lower than that of the alveolar air at rest but not after strenuous exercise. There is no anoxemia (Table IIB).

Voluntary breathing capacity in the erect posture is diminished. It is 80.6 liters or 73 per cent of the predicted value. Breath-holding time is 24 seconds in room air and 36 seconds when breathing oxygen.

The cardiac output is 0.81 liter per minute per square meter body surface area. This is an abnormally low value according to the standards used.

SUMMARY: The volume of residual air relative to the total lung volume is high. Intrapulmonary mixing of gases is impaired. Respirations are rapid and shallow. Maximum breathing capacity and breath-holding time are low. The oxygen extraction per volume of air breathed is normal. The oxygen tension studies indicate an impairment in respiratory function of the lungs at rest. These results are consistent with pulmonary emphysema. 


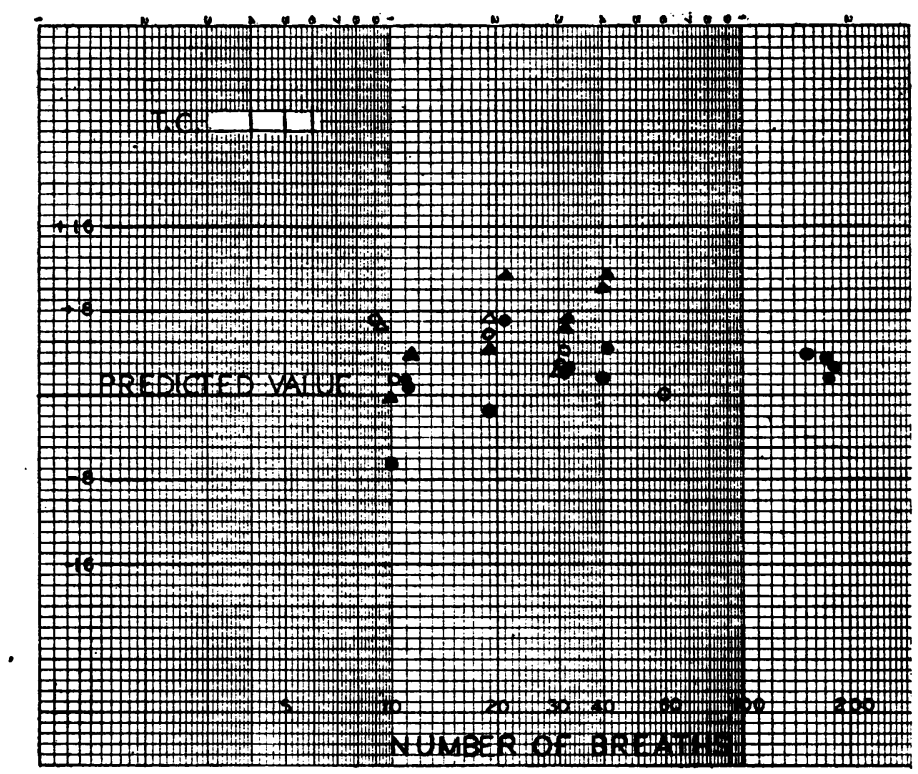

3B

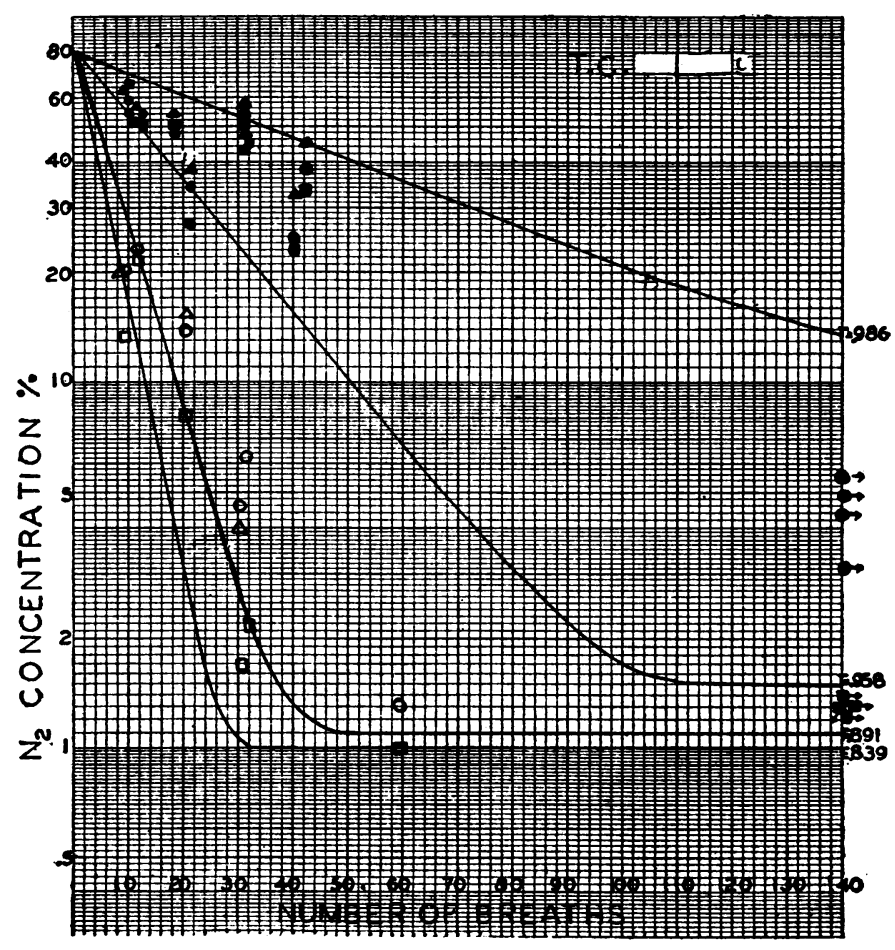

$3 \mathrm{C}$

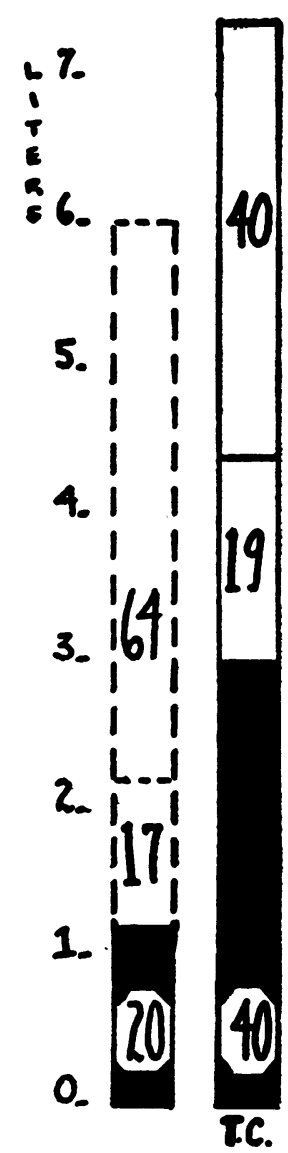

3A

Fig. 3A. Subdivisions of Lung Volume. 3B and 3C. Intrapulmonary Mixing of Gases-Tidal Air: 219$448 \mathrm{ml}$. (generally $325 \mathrm{ml}$.), voluntarily deepened 709-1066 ml. (generally $850 \mathrm{ml}$ ) DEAD SPACE: $205 \mathrm{ml}$. 
TABLE IIIA

Respiratory pattern

\begin{tabular}{|c|c|c|c|c|c|c|c|c|}
\hline \multirow{2}{*}{$\begin{array}{l}\text { Date } \\
1944\end{array}$} & \multirow{2}{*}{$\begin{array}{c}\text { Experi- } \\
\text { ment }\end{array}$} & \multirow{2}{*}{$\begin{array}{l}\text { Resp. } \\
\text { rate }\end{array}$} & \multirow{2}{*}{$\begin{array}{l}\text { Tidal } \\
\text { air }\end{array}$} & \multirow{2}{*}{$\begin{array}{l}\text { Min. } \\
\text { vol. }\end{array}$} & \multicolumn{2}{|c|}{ Alveolar air } & \multicolumn{2}{|c|}{ Expired air } \\
\hline & & & & & $\mathrm{pO}_{2}$ & $\mathrm{pCO}_{2}$ & $\mathbf{O}_{2}$ & $\mathrm{CO}_{2}$ \\
\hline $\begin{array}{l}7 / 18 \\
7 / 19\end{array}$ & $\begin{array}{l}\text { Air } \\
\mathrm{O}_{2} \\
\mathrm{O}_{2} \\
\mathrm{O}_{2} \\
\mathrm{O}_{2}\end{array}$ & $\begin{array}{l}28.5 \\
21.5 \\
24.0 \\
21.0 \\
22.0\end{array}$ & $\begin{array}{l}m l . \\
342 \\
356 \\
347 \\
390 \\
318\end{array}$ & $\begin{array}{c}l . \\
9.76 \\
7.73 \\
8.44 \\
7.75 \\
7.05\end{array}$ & $\begin{array}{r}92.4 \\
630.0 \\
643.0 \\
621.0 \\
630.0\end{array}$ & $\begin{array}{l}39.5 \\
45.2 \\
45.1 \\
49.2 \\
53.1\end{array}$ & $\begin{array}{c}\text { per } \\
\text { cent } \\
17.75 \\
= \\
= \\
=\end{array}$ & $\begin{array}{l}\text { per } \\
\text { cent } \\
2.43 \\
= \\
=\end{array}$ \\
\hline
\end{tabular}

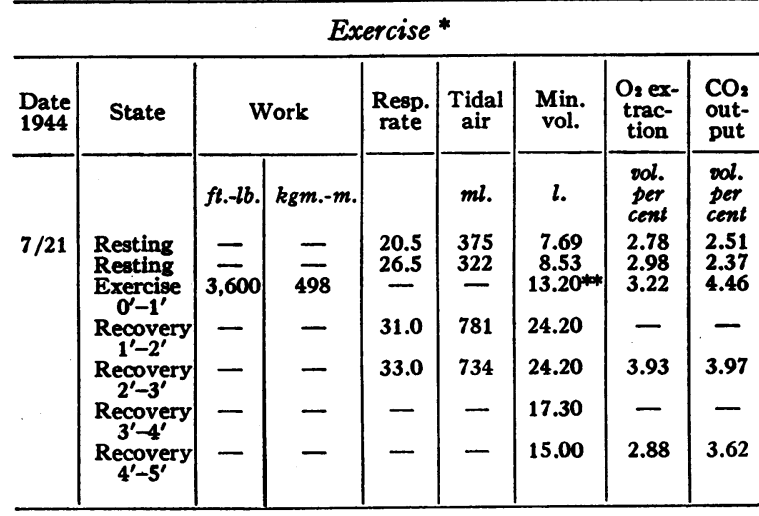

* Step test.

** Some expired air lost.

Case 3 (T. C., Male, Age 24, Record No. 326880).

Height $180 \mathrm{~cm}$. , Weight $61.1 \mathrm{kgm}$., Surface Area $1.77 \mathrm{M}^{2}$.

The patient voluntarily entered the Johns Hopkins Hospital on July 16, 1944, for pulmonary function studies.

He has suffered from asthma during June and October since childhood. Subcutaneous injections of adrenalin afford prompt relief.

The patient worked in the chlorine plant during the winter of 1941 and had several minor exposures to chlorine.

He has worked in the phosgene plant since early 1942 and has at least on 6 occasions inhaled sufficient phosgene to cause him to experience immediate coughing, choking sensation, sweating, nausea and vomiting, and headache. $\mathrm{He}$ usually is fully recovered by the following day. He last inhaled phosgene in June, 1944, approximately 1 month prior to admission to the hospital.

Since 1942, the patient has experienced shortness of breath and dizziness on moderate exertion.

At the time of his admission to the hospital, the only positive findings noted on physical examination were kyphosis of the thoracic vertebrae and a few sonorous rales over the base of each lung.

A teleoroentgenogram showed voluminous, clear lungs, an emphysematous chest and a normal-sized heart. The red blood cell and total and differential white blood cell counts, level of hemoglobin, volume of packed red blood cells, and urine were normal.

When last examined in January, 1945, approximately 6 months after the initial examination, the patient was still working in the phosgene plant. There were no new complaints or physical findings and the symptoms presented on the first admission were still present.

PSYCHIATRIC SUMMARY: T. C. seems to be a stable, hard working, conscientious individual of average intelligence, who is in no acute distress at the present time, January 19, 1945. He returns to the hospital for followup study and more careful evaluation. His exposures, though repeated, were not very serious and he was able to take them in his stride without their being particularly distressing or seriously altering his personal functioning. $\mathrm{He}$ is a quite mature man with a very sensible attitude toward his life's problems in general. His emotional reaction and present personal adjustment fall well within the normal range, and there seems to be little evidence that his personality structure or personal adjustment has been substantially influenced by his exposures at work.

PULMONARY FUNCTION STUDIES: The vital capacity is at the lower limit of normal predicted values. The residual air and mid-capacity volumes are abnormally high. Vital capacity and complementary air comprise an abnormally low percentage of the total lung volume and residual air and mid-capacity an abnormally high percentage (Figure $3 \mathrm{~A}$ ).

Respiration at rest when room air or oxygen is breathed is rapid and shallow. The minute volume is high. During exercise the rate of respiration increases moderately, the depth more than doubles, and the minute volume falls within the normal range (Table IIIA).

Intrapulmonary mixing of gases is impaired during quiet breathing when the dilution rate is slow and during voluntarily deepened breathing when the dilution rate is rapid. Pulmonary emptying rate is slow (Figures 3B, 3C).

TABLE IIIB

Arterial blood studies

\begin{tabular}{c|c|c|c|c}
\hline \hline Date 1944 & State & $O_{2}$ content & $O_{2}$ capacity & Saturation \\
\cline { 2 - 4 } $7 / 21$ & Resting & $\begin{array}{c}\text { vol. per cent } \\
20.0\end{array}$ & $\begin{array}{c}\text { vol. per cent } \\
21.1\end{array}$ & $\begin{array}{c}\text { per cent } \\
95.3\end{array}$ \\
\hline
\end{tabular}

\begin{tabular}{|c|c|c|c|c|c|c|c|c|}
\hline \multirow{3}{*}{$\begin{array}{l}\text { Date } \\
1945\end{array}$} & \multirow{3}{*}{ State } & \multicolumn{2}{|c|}{ Oxygen tension } & \multicolumn{3}{|c|}{$\begin{array}{c}\text { Carbon dioxide } \\
\text { tension }\end{array}$} & \multirow{3}{*}{$\begin{array}{l}\mathrm{CO}_{2} \\
\text { con- } \\
\text { tent }\end{array}$} & \multirow{3}{*}{$\begin{array}{l}\text { Se- } \\
\text { rum } \\
\text { pH }\end{array}$} \\
\hline & & \multirow{2}{*}{$\begin{array}{l}\text { Alv. } \\
\text { air }\end{array}$} & \multirow{2}{*}{ Art. blood } & \multirow{2}{*}{$\begin{array}{c}\text { Alv. } \\
\text { air }\end{array}$} & \multicolumn{2}{|c|}{$\begin{array}{c}\text { Arterial } \\
\text { blood }\end{array}$} & & \\
\hline & & & & & $\begin{array}{l}\mathrm{Di}- \\
\text { rect }\end{array}$ & $\begin{array}{l}\text { Calcu- } \\
\text { lated }\end{array}$ & & \\
\hline \multirow{5}{*}{$\begin{array}{l}1 / 19 \\
1 / 20\end{array}$} & \multirow{5}{*}{$\begin{array}{l}\text { Resting } \\
\text { Resting } \\
\text { After exercise } \\
1 \text { min. } \\
5 \text { min. } \\
1 \text { min. (less } \\
\text { severe) } \\
3 \text { min. (less } \\
\text { severe) }\end{array}$} & \multicolumn{2}{|r|}{$m m . H_{g}$} & \multicolumn{3}{|c|}{$m m . H g$} & $\begin{array}{l}\text { vol. } \\
\text { per } \\
\text { cent }\end{array}$ & \\
\hline & & $\begin{array}{l}99 \\
99\end{array}$ & $\begin{array}{c}98(98-99) \\
103(102-107)\end{array}$ & $\underline{45}$ & $\underline{44}$ & $\underline{41}$ & 58.8 & 7.41 \\
\hline & & $\begin{array}{l}124 \\
115\end{array}$ & $\begin{array}{l}104(102-105) \\
103(102-107)\end{array}$ & $\begin{array}{l}39 \\
39\end{array}$ & 38 & $\begin{array}{l}39 \\
36\end{array}$ & $\begin{array}{l}48.0 \\
47.6\end{array}$ & $\begin{array}{l}7.34 \\
7.38\end{array}$ \\
\hline & & 118 & $109(108-110)$ & 43 & 38 & - & - & - \\
\hline & & 119 & $114(113-115)$ & 38 & 43 & - & - & - \\
\hline
\end{tabular}




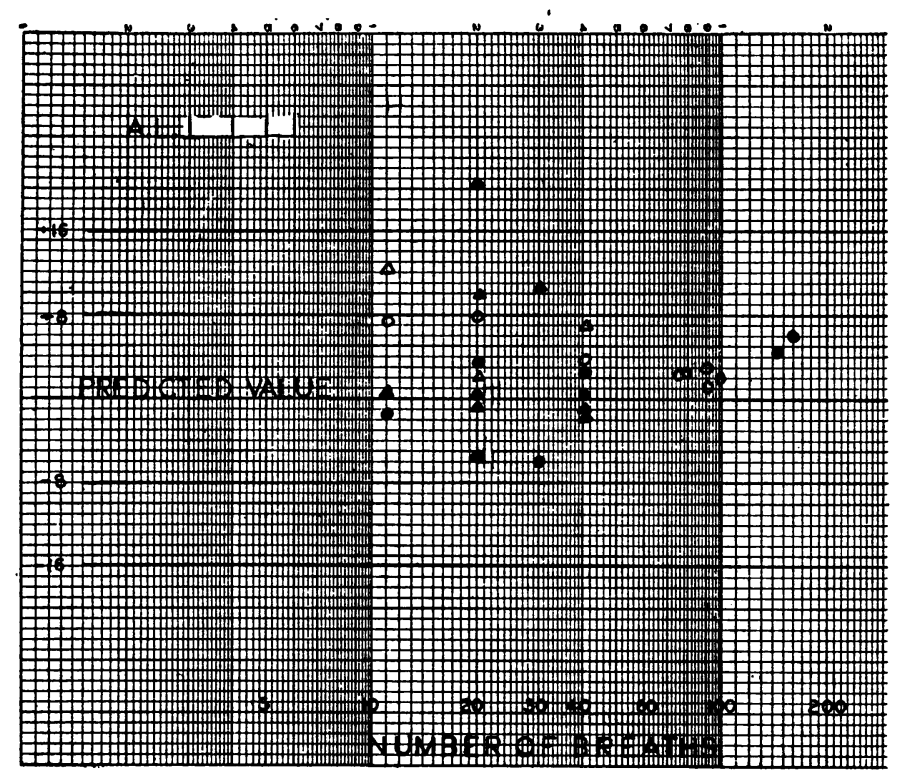

4B

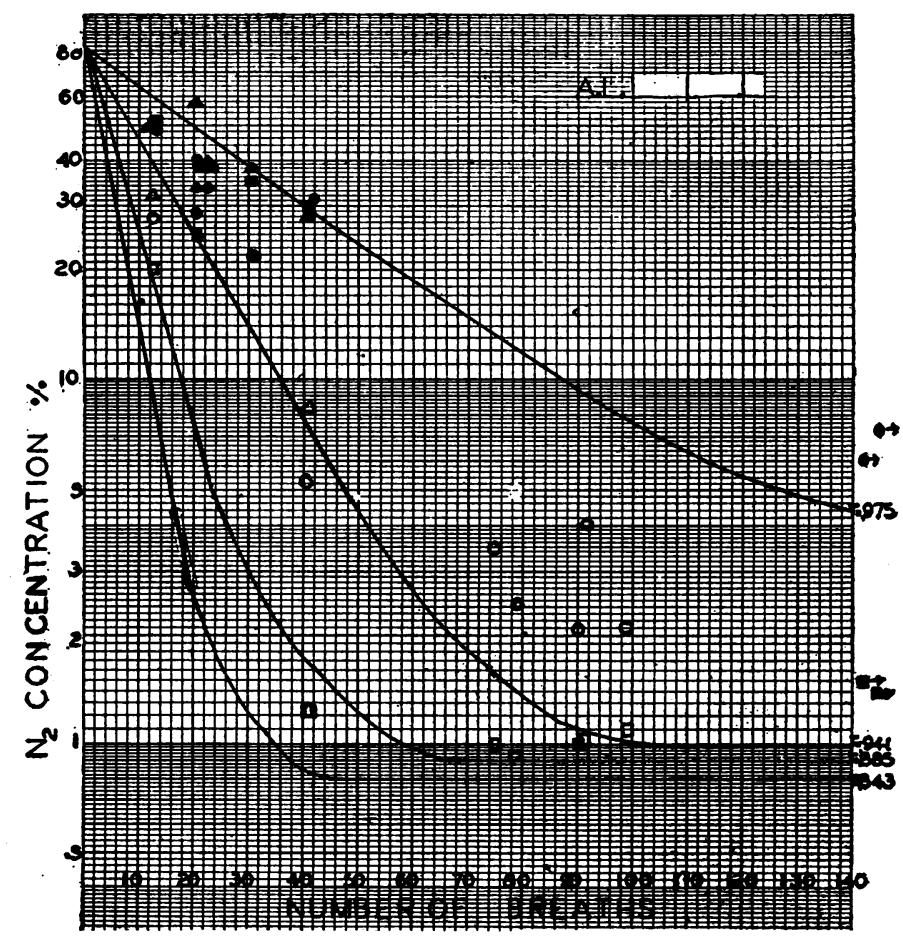

$4 \mathrm{C}$

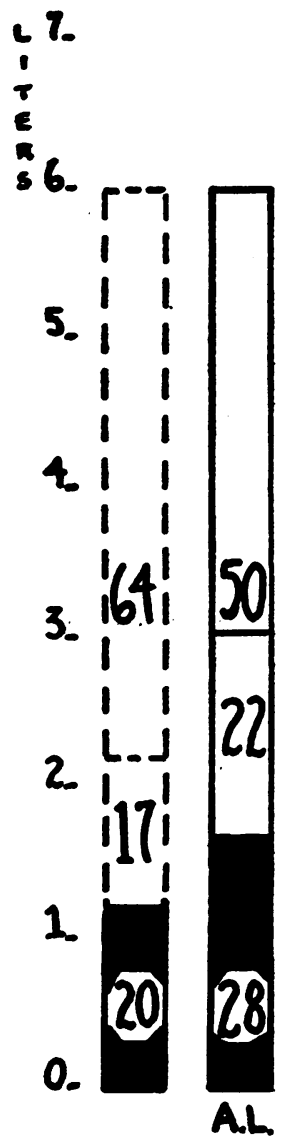

$4 \mathrm{~A}$

Fig. 4A. Subdivisions of Lung Volume. 4B and 4C. Intrapulmonary Mixing of Gases-Tidal Air: 340$460 \mathrm{ml}$. (generally $380 \mathrm{ml}$.), voluntarily deepened 669-889 ml. (generally $750 \mathrm{ml}$.). DeAd SPACE: $262 \mathrm{ml}$. 
The oxygen extraction and the carbon dioxide output at rest per volume of air breathed are at the lower range of normal. During exercise, the oxygen extraction per volume of air breathed is subnormal, but carbon dioxide concentration is normal. During the first 3 minutes of recovery from exercise, the oxygen extraction rises to the normal range and during the fourth minute falls to its resting level. The carbon dioxide concentration is normal during the recovery period (Table IIIA).

These findings are consistent with the results of the arterial blood and alveolar air oxygen and carbon dioxide tension studies (Table IIIB). At rest there is no disturbance in oxygen transfer in the lungs. During strenuous exercise the alveolar air oxygen tension is approximately $20 \mathrm{~mm}$. $\mathrm{Hg}$ greater than that of the arterial blood. This suggests the presence of a large number of inadequately circulated alveoli. There is no anoxemia.

The voluntary breathing capacity is anly 63 per cent of the predicted value when measured in the erect posture. It measures 82.6 liters. The cardiac output is 1.62 liters per minute per square meter body surface area. This is a normal value.

SUMMARY : Pulmonary ventilation is definitely impaired, as indicated by a low vital capacity and a high midcapacity and residual air, abnormally low voluntary breathing capacity, impaired intrapulmonary mixing of gases, and slow pulmonary emptying rate. Respiratory function is adequate at rest and impaired during exercise. These findings are consistent with pulmonary emphysema.

Case 4 (A. L., Male, Age 31, Record No. 309556). Height $173 \mathrm{~cm}$., Weight $62.5 \mathrm{kgm}$., Surface Area $1.74 \mathrm{M}^{2}$.

The patient voluntarily entered the Johns Hopkins Hospital on August 9, 1944, for pulmonary function studies.

The patient has worked in the Production Division, Edgewood Arsenal, since 1940. In July and November, 1942, he accidentally inhaled chlorine and experienced tightness of the chest for a few days.

In the spring of 1943 there was a recurrence of pain and tightness in the chest and an episode of bronchitis, laryngitis, and aphonia following inhalation of mustard vapor.

He began to work in the phosgene plant in the fall of 1943. In March and April, 1944, and during the summer of 1944 , he had some minor exposures to phosgene which caused shortness of breath on moderate exertion and sticking pain in the chest. These symptoms along with ease of fatigue, anorexia, and occasional nausea were still present when the patient entered the hospital.

In December, 1943, he was found by the Diagnostic Clinic of the Johns Hopkins Hospital to be suffering from chronic otitis media of the right ear, chronic tonsillitis and adenoiditis, and a somewhat inadequate personality makeup.

The only positive findings noted on physical examination when he entered the hospital for pulmonary function studies were perforation of the right ear drum and a few sonorous rales at the base of each lung. He expectorated one to two ounces of glairy, white, non-foul smelling sputum a day.

Roentgenograms of the lungs taken in March and April, 1944, and during observation in the hospital exhibited only an old obliteration of the left costophrenic angle.

When last seen in January, 1945, there were no new complaints or physical findings. The symptoms previously noted were still present.

PSYCHIATRIC SUMMARY: A. L. is a man who was seen in 1943. At this time (October 20, 1944) he has no new complaints. As far as could be determined there had been no definite exposure and certainly no recent one. His desire for medical examination is, it would seem, largely related to his underlying uneasiness and general apprehension. For the most part he more or less continuously experiences symptoms of nervousness and shakiness, along with numbness, coldness, and pain over the left side of his face; these symptoms appear to be episodically exaggerated when he is under additional emotional stress. In a setting of difficult working conditions, an unresolved love affair with concern about marriage, the burden of taking care of an invalid father, and many other family responsibilities, he has grown increasingly tense, anxious, and restless. $\mathrm{He}$ dislikes his working conditions, is frankly frightened a great deal of the time, and experiences considerable turmoil resulting from conflict about not being in the army. It is interesting to note, though, that he apparently got some benefit from his previous interview and examination, following which he seems to have settled down some and to have been able to continue with his work Clinically, his present condition might be characterized as an anxiety 'state occurring in a somewhat ineffectual and inadequate personality, in a setting of emotional turmoil coincidental with his personal problems and situational stresses. While, at present, he seems to be making a neurotic adjustment, it is easily conceivable that his personality disorganization could progress to the point where it might well be thought of as a more frankly schizophrenic disorder.

PULMONARY FUNCTION STUDIES: Vital capacity is normal. The ratio of residual air and of mid-capacity to total capacity is in the upper range of normal (Figure 4A).

The respiratory rate at rest is rapid, the tidal air is at the lower limit of normal, and the minute volume is high. The alveolar air oxygen and carbon dioxide tensions are normal. During the exercise step test the minute volume of respiration increases within normal limits primarily due to a rise in tidal air (Table IVA).

The oxygen extraction per volume of ventilation at rest and during exercise is abnormally low. The carbon dioxide output at rest is low and during exercise and recovery is at the lower limits of normal. There is no deficiency in the oxygen uptake and the carbon dioxide output per minute because of the large minute volume of respiration (Table IVA).

The dilution rate is slow and mixing is abnormal. Impaired mixing persists even when the dilution rate is increased by voluntary deep breathing. The pulmonary emptying rate is abnormally slow (Figures $4 \mathrm{~B}, 4 \mathrm{C}$ ). 


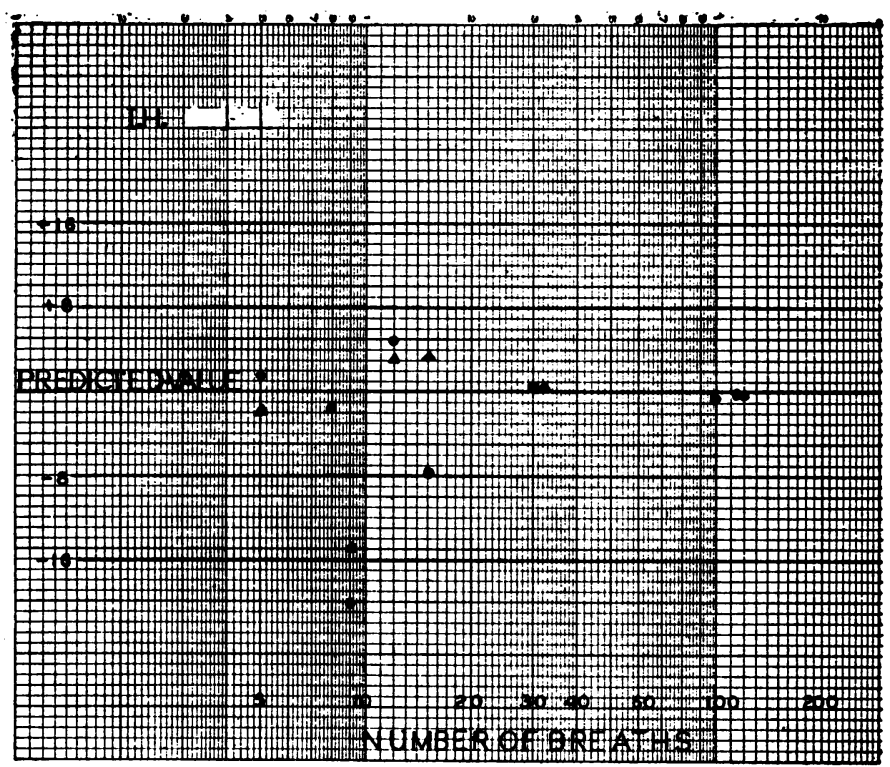

5B

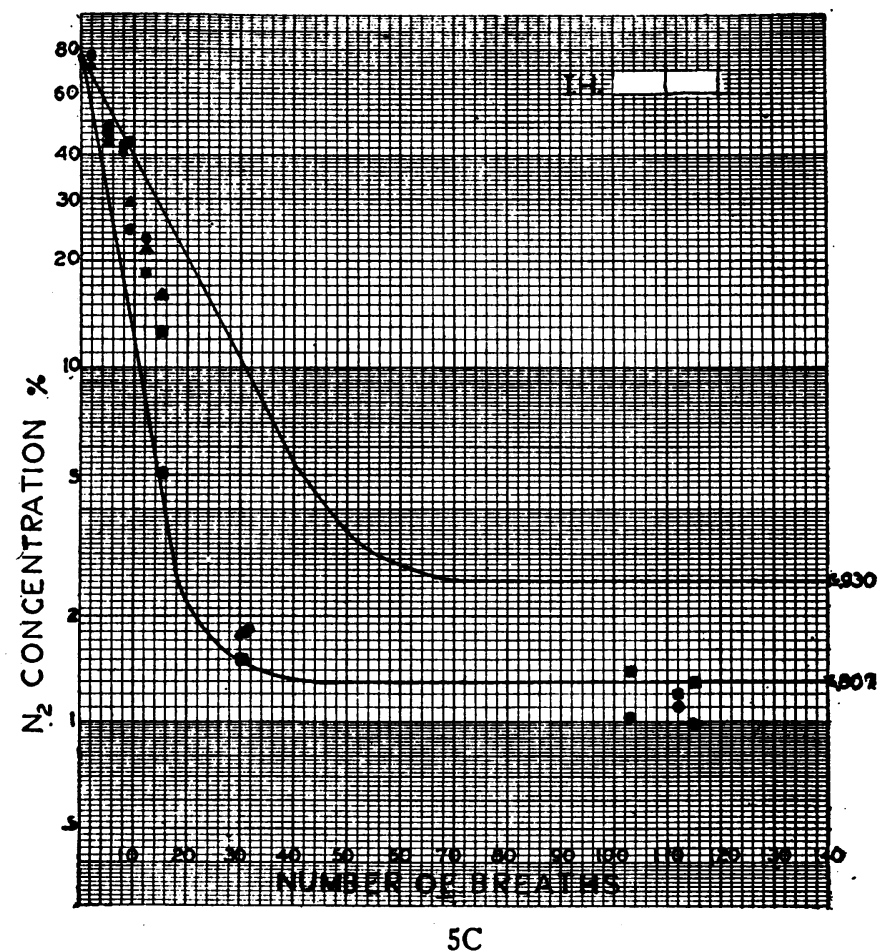

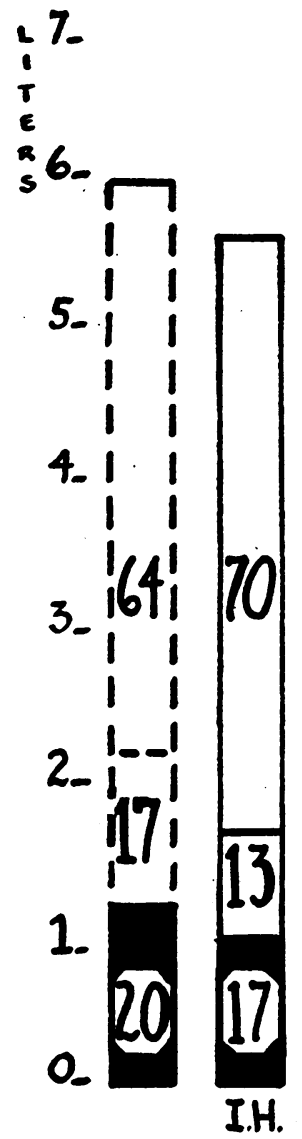

5A

Fig. 5A. Subdivisions of Lung Volume. 5B and 5C. Intrapulmonary Mixing of Gases-Tidal Air: 233$670 \mathrm{ml}$. (generally $525 \mathrm{ml}$.). Dead Space: $245 \mathrm{ml}$, 
TABLE IVA

Respiratory pattern resting

\begin{tabular}{|c|c|c|c|c|c|c|c|c|}
\hline \multirow{2}{*}{$\begin{array}{l}\text { Date } \\
1944\end{array}$} & \multirow{2}{*}{$\begin{array}{c}\text { Experi- } \\
\text { ment }\end{array}$} & \multirow{2}{*}{$\begin{array}{l}\text { Resp } \\
\text { rate }\end{array}$} & \multirow{2}{*}{$\begin{array}{c}\text { Tidal } \\
\text { air }\end{array}$} & \multirow{2}{*}{$\begin{array}{c}\text { Min. } \\
\text { vol. }\end{array}$} & \multicolumn{2}{|c|}{ Alveolar air } & \multicolumn{2}{|c|}{ Expired air } \\
\hline & & & & & $\mathrm{pO}_{2}$ & $\mathrm{pCO}_{2}$ & $\mathrm{O}_{2}$ & $\mathrm{CO}_{2}$ \\
\hline & & & $m l$. & $l$. & & & $\begin{array}{l}\text { per } \\
\text { cent }\end{array}$ & $\begin{array}{l}\text { per } \\
\text { cent }\end{array}$ \\
\hline $7 / 31$ & $\begin{array}{l}\mathrm{Air} \\
\mathrm{O}_{2}\end{array}$ & $\begin{array}{l}25.5 \\
23.5\end{array}$ & $\begin{array}{l}424 \\
406\end{array}$ & $\begin{array}{r}10.80 \\
9.50\end{array}$ & $\begin{array}{r}90.5 \\
625.0\end{array}$ & \begin{tabular}{|l|}
39.6 \\
41.8
\end{tabular} & 17.8 & 2.30 \\
\hline & $\mathrm{O}_{2}$ & 26 & 383 & 10.07 & 623.0 & 35.0 & 二 & 二 \\
\hline $\begin{array}{l}8 / 1 \\
8 / 2\end{array}$ & Air & 27 & $\overline{488}$ & \begin{tabular}{|l}
13.41 \\
13.14
\end{tabular} & 94.0 & \begin{tabular}{|l|}
30.1 \\
36.0
\end{tabular} & $\overline{18.5}$ & 2.39 \\
\hline
\end{tabular}

Exercise *

\begin{tabular}{|c|c|c|c|c|c|c|c|c|}
\hline \multirow[t]{2}{*}{$\begin{array}{c}\text { Date } \\
1944\end{array}$} & State & \multicolumn{2}{|c|}{ Work } & $\begin{array}{l}\text { Resp. } \\
\text { rate }\end{array}$ & $\begin{array}{c}\text { Tidal } \\
\text { air }\end{array}$ & $\underset{\text { vol. }}{\text { Min. }}$ & trac- & $\begin{array}{l}\mathrm{CO}_{2} \\
\text { out- }\end{array}$ \\
\hline & & $f t .-l b$. & kgm.-m. & & $m l$. & $l$. & $\begin{array}{l}\text { ool. } \\
\text { per }\end{array}$ & $\begin{array}{l}\text { nol. } \\
\text { per }\end{array}$ \\
\hline $8 / 5$ & $\begin{array}{l}\text { Resting } \\
\text { Exercise }\end{array}$ & $\overline{3,67 C}$ & $\overline{509}$ & 20 & 633 & $\begin{array}{l}12.66 \\
24.80\end{array}$ & $\begin{array}{l}2.43 \\
3.13\end{array}$ & $\begin{array}{l}2.10 \\
2.80\end{array}$ \\
\hline & Recovery & - & - & 24 & 985 & 23.60 & - & - \\
\hline & Recovery & - & - & 25 & 808 & 20.30 & 2.93 & 3.08 \\
\hline & Recovery & - & - & 29 & 594 & 17.20 & - & - \\
\hline & $\begin{array}{c}3-4^{\prime} \\
\text { Recovery } \\
4^{\prime}-5^{\prime}\end{array}$ & - & - & - & - & 11.00 & 2.31 & 2.58 \\
\hline
\end{tabular}

* Step test.

The oxygen tensions of alveolar and of arterial blood are low during rest but not sufficient to cause anoxemia. During strenuous exercise, the tension studies suggest the presence of many poorly circulated alveoli since the oxygen tension of the alveolar air ( 5 minutes after exercise) is $13 \mathrm{~mm}$. $\mathrm{Hg}$ greater than that of the arterial blood (Table IVB).

The voluntary breathing capacity is $\mathbf{1 1 0 . 0}$ liters or $\mathbf{8 9 . 9}$ per cent of the predicted volume in the erect posture. Breath-holding time is normal. The cardiac output is 1.62 liters per square meter body surface area. This is a normal value.

TABLE IVB

Arterial blood studies

\begin{tabular}{|c|c|c|c|c|c|c|c|c|}
\hline \multirow{3}{*}{$\begin{array}{l}\text { Date } \\
1945\end{array}$} & \multirow{3}{*}{ State } & \multicolumn{2}{|c|}{ Oxygen tension } & \multicolumn{3}{|c|}{$\begin{array}{c}\text { Carbon dioxide } \\
\text { tension }\end{array}$} & \multirow{3}{*}{$\begin{array}{l}\mathrm{CO}_{2} \\
\text { con- } \\
\text { tent }\end{array}$} & \multirow{3}{*}{$\begin{array}{c}\text { Se- } \\
\text { rum } \\
\text { pH }\end{array}$} \\
\hline & & \multirow{2}{*}{$\begin{array}{l}\text { Alv. } \\
\text { air }\end{array}$} & \multirow{2}{*}{ Art. blood } & \multirow{2}{*}{$\begin{array}{l}\text { Alv. } \\
\text { air }\end{array}$} & \multicolumn{2}{|c|}{$\begin{array}{l}\text { Arterial } \\
\text { blood }\end{array}$} & & \\
\hline & & & & & $\begin{array}{l}\text { Di- } \\
\text { rect }\end{array}$ & $\begin{array}{l}\text { Calcu- } \\
\text { lated }\end{array}$ & & \\
\hline \multirow{3}{*}{$\begin{array}{l}1 / 23 \\
1 / 24\end{array}$} & \multirow{3}{*}{$\begin{array}{l}\text { Resting } \\
\text { Resting } \\
\text { After exercise } \\
\quad 1 \text { min.* } \\
\quad 5 \text { min. }\end{array}$} & \multicolumn{2}{|r|}{$m m . H g$} & \multicolumn{3}{|c|}{$m m . H_{\boldsymbol{B}}$} & $\begin{array}{l}\text { vol. } \\
\text { per } \\
\text { cent }\end{array}$ & \\
\hline & & 80 & $79(74-83)$ & 41 & 36 & 41 & 56.8 & 7.40 \\
\hline & & $\begin{array}{r}93 \\
118\end{array}$ & $\begin{array}{c}99(98-100) \\
105(103-107)\end{array}$ & $\begin{array}{l}52 \\
35\end{array}$ & $\begin{array}{l}41 \\
31\end{array}$ & $\begin{array}{l}43 \\
32\end{array}$ & $\begin{array}{l}51.2 \\
45.5\end{array}$ & $\begin{array}{l}7.30 \\
7.41\end{array}$ \\
\hline
\end{tabular}

* Held breath before delivered alveolar air sample. Note high alveolar air $\mathrm{pCO}_{2}$.
SUMMARY: The residual air and mid-capacity are large in relation to the total capacity. Intrapulmonary mixing of gases is impaired and pulmonary emptying rate is slow. Voluntary breathing capacity is not reduced. Respiratory function is adequate at rest and impaired during exercise. These findings are consistent with pulmonary emphysema.

Case 5 (1. H., Male, Age 26, Record No. 330150).

Height $170 \mathrm{~cm}$., Weight 79.2 kgm., Surface Area $1.90 \mathrm{M}^{2}$.

The patient voluntarily entered the Johns Hopkins Hospital on August 20,1944, for pulmonary function tests.

He worked in the phosgene plant from January, 1942 to February, 1943, in the chlorine plant from February, 1943 to November, 1943, and again in the phosgene plant from November, 1943, until admission to the hospital.

He has had a few minor exposures to phosgene which caused burning and watering of the eyes, cough, tightness in the chest, and headache. These symptoms have not at any time been disabling.

The patient has noticed moderate shortness of breath on exertion, tightness in the chest, and occasional attacks of coughing since the fall of 1943.

At the time of his admission to the hospital no abnormalities were noted on physical examination.

A roentgenogram of the lungs and heart appeared normal. There was no anemia. The total and differential white blood counts and urine were normal.

Shortly after discharge from the hospital the patient joined the Navy.

PULMONARY FUNCTION STUDIES: The relationship among the components of the total lung volume is normal (Figure 5A). The rate of breathing, tidal air, and minute

TABLE VA

Respiratory pattern resting

\begin{tabular}{|c|c|c|c|c|c|c|c|c|}
\hline \multirow{2}{*}{$\begin{array}{l}\text { Date } \\
1944\end{array}$} & \multirow{2}{*}{$\begin{array}{c}\text { Experi- } \\
\text { ment }\end{array}$} & \multirow{2}{*}{$\begin{array}{l}\text { Resp. } \\
\text { rate }\end{array}$} & \multirow{2}{*}{$\begin{array}{l}\text { Tidal } \\
\text { air }\end{array}$} & \multirow{2}{*}{$\begin{array}{l}\text { Min. } \\
\text { vol. }\end{array}$} & \multicolumn{2}{|c|}{ Alveolar air } & \multicolumn{2}{|c|}{ Expired air } \\
\hline & & & & & $\mathrm{pO}_{2}$ & $\mathrm{pCO}_{2}$ & $\mathrm{O}_{2}$ & $\mathrm{CO}_{2}$ \\
\hline $8 / 23$ & $\begin{array}{l}\mathrm{O}_{2} \\
\mathrm{O}_{2} \\
\mathrm{Air} \\
\mathrm{Air} \\
\mathrm{Air} \\
\mathrm{O}_{2}\end{array}$ & $\begin{array}{l}14 \\
16 \\
15 \\
13 \\
13 \\
15.5\end{array}$ & $\begin{array}{l}\mathrm{ml} . \\
\mathbf{5 5 2} \\
541 \\
502 \\
562 \\
564 \\
528\end{array}$ & $\begin{array}{c}l . \\
7.73 \\
\mathbf{8 . 7 4} \\
\mathbf{7 . 4 5} \\
\mathbf{7 . 3 6} \\
\mathbf{7 . 4 7} \\
\mathbf{8 . 2 5}\end{array}$ & $\begin{array}{c}669.0 \\
\overline{95.1} \\
92.6 \\
79.2 \\
\end{array}$ & $\begin{array}{c}37.8 \\
\overline{33.7} \\
43.6 \\
42.2 \\
-\end{array}$ & $\begin{array}{c}\text { per } \\
\text { cent } \\
- \\
\overline{-} \\
16.93 \\
16.80 \\
16.24\end{array}$ & $\begin{array}{c}\text { per } \\
\text { cent } \\
- \\
- \\
2.68 \\
3.62 \\
3.75\end{array}$ \\
\hline
\end{tabular}

Exercise *

\begin{tabular}{|c|c|c|c|c|c|c|c|c|}
\hline \multirow[t]{2}{*}{$\begin{array}{l}\text { Date } \\
1944\end{array}$} & State & \multicolumn{2}{|c|}{ Work } & $\begin{array}{l}\text { Resp. } \\
\text { rate }\end{array}$ & $\begin{array}{l}\text { Tidal } \\
\text { air }\end{array}$ & $\begin{array}{l}\text { Min. } \\
\text { vol. }\end{array}$ & $\begin{array}{c}\text { Os ex- } \\
\text { trac- } \\
\text { tion }\end{array}$ & $\begin{array}{l}\mathrm{CO}_{2} \\
\text { out- } \\
\text { put }\end{array}$ \\
\hline & & & kgm.-m. & & $m l$ & $l$ & $\begin{array}{l}\text { ool. } \\
\text { per } \\
\text { cent }\end{array}$ & $\begin{array}{l}\text { ool. } \\
\text { per } \\
\text { cent }\end{array}$ \\
\hline $8 / 24$ & $\begin{array}{c}\text { Resting } \\
\text { Resting } \\
\text { Exercise } \\
0^{\prime}-1^{\prime} \\
\text { Recovery } \\
1^{\prime}-4^{\prime} \\
\text { Recovery } \\
4^{\prime}-5^{\prime}\end{array}$ & $\begin{array}{c}\overline{-} \\
4,670 \\
- \\
-\end{array}$ & $\begin{array}{l}\overline{-} \\
646 \\
- \\
-\end{array}$ & $\begin{array}{l}9 \\
9 \\
- \\
-\end{array}$ & $\begin{array}{r}1,030 \\
982 \\
- \\
- \\
-\end{array}$ & $\begin{array}{r}9.3 \\
8.9 \\
29.9 \\
17.9 \\
11.7\end{array}$ & $\begin{array}{l}4.08 \\
4.78 \\
4.75 \\
4.33 \\
3.59\end{array}$ & $\begin{array}{l}2.75 \\
3.86 \\
3.95 \\
4.68 \\
4.00\end{array}$ \\
\hline
\end{tabular}

* Step test. 
volume are within the normal range. Alveolar and expired air are normal in composition. With exercise there is an increase in the percentage carbon dioxide output and the oxygen extraction, as well as a normal rise in minute volume of respiration (Table VA). The nitrogen dilution rate is normal and there is no disturbance of intrapulmonary mixing of gases (Figures $5 \mathrm{~B}, 5 \mathrm{C}$ ).

Voluntary breathing capacity in the erect posture is abnormally low. It is 104.2 liters or 75.2 per cent of the predicted volume. Breath-holding time is normal.

SUMmary: Pulmonary function is normal except for a reduction in voluntary breathing capacity.

\section{BIBLIOGRAPHY}

1. Whitaker, P. H., An investigation into the radiological appearances of the chests of workers engaged in the production of toxic gases. Inclosure 1 to Military Attaché, London Report No. R3580-45 (A.3813)

2. Galdston, M., Luetscher, J. A., Jr., Longcope, W. T., and Ballich, Nicholas L., A study of the residual effects of phosgene poisoning in human subjects. I. After acute exposure. J. Clin. Invest., 1947, 26, 145. 